\title{
Applied Entomology and Zoology Vol. 53, No. 1 目次
}

(2018 年 2 月 25 日発行)

\section{ORIGINAL RESEARCH PAPERS}

Bidirectional movement of aphid parasitoids (Braconidae: Aphidiinae) between crops and non-crop plants in agroecosystems of central Argentina [中央アルゼンチンの農業生 態系での作物と非作物間におけるアブラムシ寄生蜂 (ハチ目：コ マユバチ科：アブラバチ亜科) の双方向移動］

Leticia Zumoffen, Marcelo Signorini, Adriana Salvo 1

Biotic performances of thelytokous and arrhenotokous strains of Thrips tabaci (Thysanoptera: Thripidae) showing resistance to cypermethrin[ネギアザミウマ（アザミウマ目： アザミウマ科) の産雌単為生殖系統と産雄単為生殖系統に打ける シペルメトリン抵抗性と生物学的パフォーマンス]

Misato Aizawa, Takeo Watanabe, Akemi Kumano, Kumie Tamagaki, Shoji Sonoda（相澤美里・渡邊丈夫 ·熊野明美 - 玉垣 くみ江・園田昌司） 11

Molecular characterization of a NADPH-cytochrome P450 reductase gene from the rice leaffolder, Cnaphalocrocis medinalis (Lepidoptera: Pyralidae) [コブノメイガ (チョウ目 : メ イガ科)に扎ける NADPH-チトクロム P450 リダクターゼ遺伝子 の分子特性解析]

Yu-Xing Zhang, Shi-Guang Li, Xiang-Jun Rao, Su Liu 19

Effects of inter-subspecies hybridization of non-native Monochamus alternatus alternatus and native M. a. endai (Coleoptera: Cerambycidae) on the induction of larval diapause and adult body size[外来のマツノマダラカミキリ Monochamus alternatus alternatus と日本産の M. a. endai の亜種間 雑種が幼虫休眠の誘起と成虫の体サイズに及ぼす影響] Katsumi Togashi, Wataru Toki（富樫一已·土岐和多留） 29

Sexual maturation of male Bactrocera correcta (Diptera: Tephritidae) and age-related responses to $\beta$-caryophyllene and methyl eugenol [セグロモモミバエ (ハエ目: ミバエ科) 雄 の性成熟並びに歯に関係した $\beta$-カリオフィレン及びメチルオイ ゲノールへの反応

Toshihisa Kamiji, Masashi Kaneda, Motonori Sasaki, Kenji Ohto (上地俊久 · 金田昌士 ·佐々木幹了・大戸謙二) 41

A preliminary study on distributions and oviposition sites of Drosophila suzukii (Diptera: Drosophilidae) and its parasitoids on wild cherry tree in Tokyo, central Japan [東京
におけるオウトウショウジョウバエ (ハエ目：ショウジョウバエ 科）とその寄生蜂のサクラ樹木上の分布と産卵場所に関する予備 的研究]

Akira Matsuura, Hideyuki Mitsui, Masahito T. Kimura (松浦 輝 · 三井偉由 · 木村正人) 47

Mung bean (Vigna radiata) cultivars mediated oviposition preference and development of Callosobruchus chinensis (Coleoptera: Chrysomelidae: Bruchinae)[アズキゾウムシ (コ ウチュウ目：ハムシ科：マメゾウムシ亜科)の産卵選好性㧊よび 発育に影響するリョクトウ品種について］

Rameswor Maharjan, Hwijong Yi, Hyuntae Kim, Youngnam Yoon, Yunwoo Jang, Soondo Bae $\mathbf{5 5}$

Potency of the mosquitocidal Cry46Ab toxin produced using a 4AaCter-tag, which facilitates formation of protein inclusion bodies in Escherichia coli [大腸菌でアルカリ可溶性 の凝集体形成を促すぺプチドタグ $4 \mathrm{AaCter}$ 利用した殺蚊 Cry46Ab トキシンの製剤化]

Tomoaki Okazaki, Junya Ichinose, So Takebe, Toru Ide, Tohru Hayakawa（岡崎友亮・ 一八瀬純也・武部 聡 - 井出 徹 - 早川 徹) 67

Monitoring thrips species with yellow sticky traps in astringent persimmon orchards in Korea [韓国の渋柿果樹園に おけるアザミウマ類の黄色粘着トラップによるモニタリング］

Md. Abdul Alim, Janghoon Song, Ho-Jin Seo, Jang-Jeon Choi $\mathbf{7 5}$

Larvae of the exotic predatory ladybird Platynaspidius maculosus (Coleoptera: Coccinellidae) on citrus trees: prey aphid species and behavioral interactions with aphid-attending ants in Japan[カンキツ樹上に打ける外来種モンクチ ビルテントウ (コウチュウ目：テントウムシ科) の幼虫：日本に おける慨アブラムシ種とアブラムシ随伴アリとの行動上の関係] Shuji Kaneko（金子修治） 85

Identification of the genes in tea leafhopper, Empoasca onukii (Hemiptera: Cicadellidae), that encode odorantbinding proteins and chemosensory proteins using transcriptome analyses of insect heads[チャノミドリヒメヨコバ イ (カメムシ目：ヨコバイ科) の頭部トランスクリプトーム解析 を利用した，におい物質結合タンパクおよび化学感覚タンパクを 
コードする遺伝子の同定］

Lei Bian, Zhao-Qun Li, Long Ma, Xiao-Ming Cai, Zong-Xiu Luo, Zong-Mao Chen 93

Host plants influence female oviposition and larval performance in West Indian sweet potato weevils Euscepes postfasciatus (Coleoptera: Curculionidae) [寄主植物がイモゾウム シ (コウチュウ目：ゾウムシ科) の産卵と幼虫パフォーマンスに 与える影響]

Kaori Tsurui-Sato, Norikuni Kumano, Atsushi Honma, Takashi Matsuyama, Dai Haraguchi, Kiyohito Teruya, Tetsuya Toyosato, Haruki Tatsuta (鶴井 (佐藤) 香織・熊野了州·本間 淳 · 松山隆志 · 原口大 · 照屋清仁 · 豊里哲也 · 立田晴 記) 107

In the presence of red light, cucumber and possibly other host plants lose their attractability to the melon thrips Thrips palmi (Thysanoptera: Thripidae) [ミナミキイロアザ ミウマ (アザミウマ目 :アザミウマ科) は赤色光を照射されたキュ ウリなどの寄主植物に誘引されない]

Mika Murata, Takahiko Hariyama, Yumi Yamahama, Mina Toyama, Izumi Ohta（村田未果·針山孝彦 - 山濱由美 - 外山美 奈·太田 泉) 117

Entomopathogenic nematode distribution and edaphoclimatic conditions in the Cerrado of Minas Gerais, Brazil[フフ ラジル，ミナスジェライス州のセラードに打ける昆虫病原性線虫 の分布と土壤 ·気象条件]

Vanessa Andaló, Jéssica Mieko, Fábio Janoni Carvalho, Gleice Aparecida de Assis, Lucas Silva de Faria, Franscinely Aparecida de Assis, Ronaldo Antônio dos Santos, Francielle Rosa 129

Effects of ambient temperature and the mud snail Cipangopaludina chinensis laeta (Architaenioglossa: Viviparidae) on performance of rice plants [タニシ (原始紐 舌目：タニシ科）と温度がイネの生育に及ぼす影響]

Andreas Hendracipta Kurniawan, Satoru Sato, Hironori Yasuda (Andreas Hendracipta Kurniawan ·佐藤 智 · 安田弘法) 137
Feeding behaviors of rice-ear bugs, Trigonotylus caelestialium and Stenotus rubrovittatus (Hemiptera: Miridae), in response to starch and its related substances[デンプンおよ びその関連物質に対するアカヒゲホソミドリカスミカメとアカス ジカスミメ (カメムシ目：カスミカメムシ科) の吸汁行動] Masatoshi Hori, Sachiyo Naito (堀 雅敏・内藤幸世) 143

\section{TECHNICAL NOTE}

Development and validation of microsatellite markers for the tiny dragonfly, Nannophya pygmaea (Odonata: Libellulidae), which is endangered in South Korea [韓国で 絶滅危惧種であるハッチョウトンボ (トンボ目：トンボ科)のた めのマイクロサテライトマーカーの開発と検証]

Min Jee Kim, Ah Rha Wang, Sung Soo Kim, Junghwa An, Iksoo Kim 151

Appropriate number of inoculated eggs for mass-rearing the West Indian sweet potato weevil, Euscepes postfasciatus (Coleoptera: Curculionidae) [イモゾウムシ (コウチュウ目：ゾ ウムシ科) の大量飼育法における適切な卵接種量］

Chihiro Himuro, Norikuni Kumano, Atsushi Honma, Yusuke Ikegawa, Tsuyoshi Ohishi (日室千尋 · 熊野了州 ·本間 淳 · 池 川雄亮 ·大石 毅) 157

A simple method of monitoring for cypermethrin resistance in Thrips tabaci (Thysanoptera: Thripidae) using agar-coated glass pipettes [寒天でコーティングしたガラスピ ペットを用いたネギアザミウマ(アザミウマ目：アザミウマ科) のシペルメトリン抵抗性の簡易モニタリング法］

Misato Aizawa, Kiyohiro Nakai, Takeo Watanabe, Akemi Kumano, Kumie Tamagaki, Shoji Sonoda (相澤美里 - 中井清 裕 · 渡邊丈夫 · 熊野明美 - 玉垣くみ江 · 園田昌司) 165

\section{CORRECTION}

Correction to: Small-scale rearing of the black soldier fly, Hermetia illucens (Diptera: Stratiomyidae), in the laboratory: low-cost and year-round rearing[正誤表:アメリカミ ズアブ (ハエ目：ミズアブ科) の室内小規模飼育: 周年安価飼育法] Satoshi Nakamura, Ryoko T. Ichiki, Masami Shimoda, Shinsuke Morioka (中村 達 - 一木良子 . 霜田政美 - 森岡伸 介) 165 